\title{
Light on the Waves: Science, music, poetry... and light!
}

\section{Marta Garcia-Matos, Silvia Carrasco}

Marta Garcia-Matos, Silvia Carrasco, "Light on the Waves: Science, music, poetry... and light!," Proc. SPIE 9289, 12th Education and Training in Optics and Photonics Conference, 92892E (17 July 2014); doi: 10.1117/12.2070733

SPIE Event: 12th Education and Training in Optics and Photonics Conference, 2013, Porto, Portugal 


\title{
Light on the Waves - Science, music, poetry... and light!
}

\author{
Marta Garcia-Matos and Silvia Carrasco \\ ICFO - Institut de Ciencies Fotoniques, Mediterranean Technology Park, 08860 Castelldefels \\ Barcelona, Spain.
}

\begin{abstract}
A contest proposal addressed to high-school students at centers across Catalonia is described. The aim of the initiative is to raise awareness of photonics in high schools as well as to explore the role of humanities in science teaching and outreach. A detailed account of the first edition of the activity, with data on participation, results, impact, and feedback from teachers, musicians, and students is presented.

Keywords: Optics education, photonics education, optics outreach, music, literature, science fiction, light, young writers.

\section{INTRODUCTION}

Our objective when launching a literary contest about light was to help to increase awareness of photonics in high-school students by putting photonics at the center of a creative effort and tying it to subjects and areas of interest that are not always immediately associated with science. However, standing as a competitive contest in Catalonia represents a serious challenge, since the region has a strong tradition in writing contests for schools. In particular, the prestigious "Fem contes de ciència" (Let's write science tales) competition, organized by Barcelona's Science Museum CosmoCaixa ${ }^{1}$ is a classic running for more than ten years now.
\end{abstract}

In this paper we explain how we gave a twist to the prize of the contest to be competitive, and how this twist affected the structure of the whole project. The key ingredient of the prize was to make the winning selections highly visible. We considered 10 winners. As a prize, each one met a different musical band to witness how they composed a song based on his/her lyrics. As a result, the outcomes of the contest, i.e., the songs, became outreach pieces themselves, involving in the project the general public, teachers, students and musicians. The project was named Light on the Waves ${ }^{2}$.

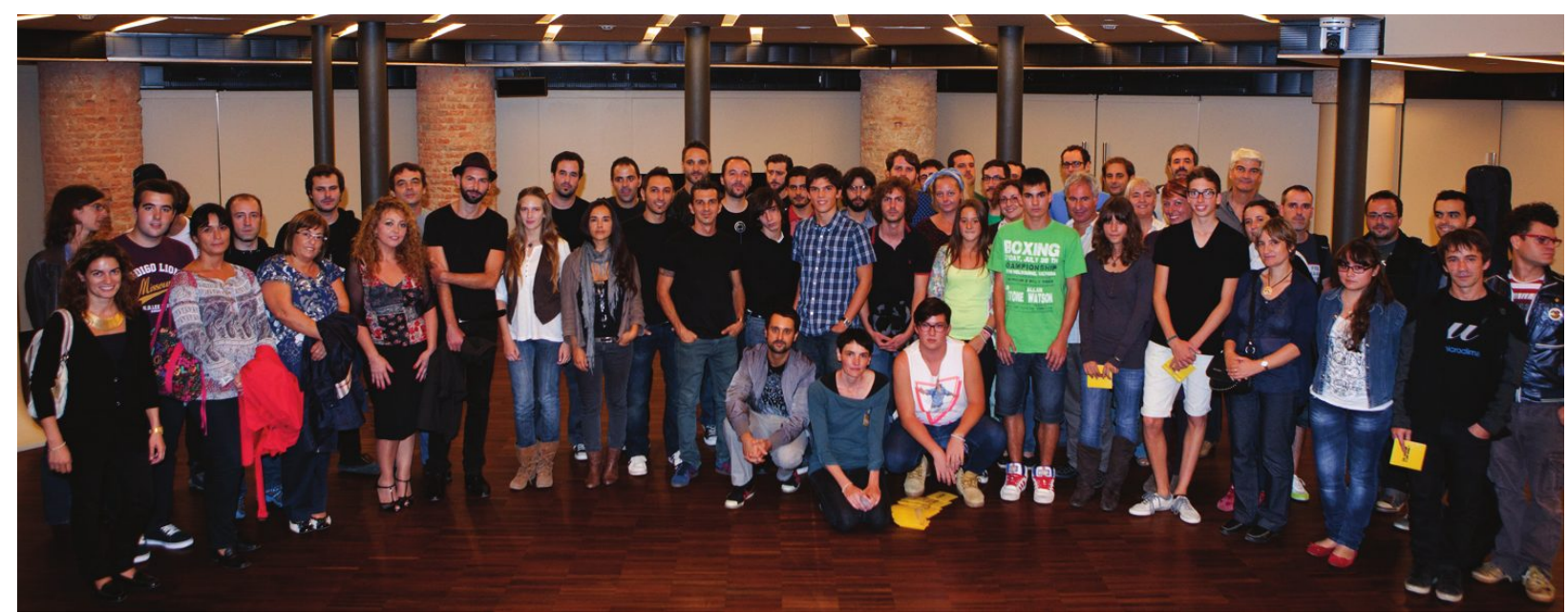

Figure 1. Participants (teachers, students, and musicians) of the first edition of Light on the Waves, gathering at the end of the concert in La Pedrera, Barcelona, on 28.9.12. CPepe Molina

12th Education and Training in Optics and Photonics Conference, edited by Manuel F. P. C. Martins Costa, Mourad Zghal, Proc. of SPIE Vol. 9289, 92892E

(C) 2014 SPIE, OSA, IEEE, ICO · doi: 10.1117/12.2070733 


\section{ELEMENTS}

\subsection{Contest rules}

The contest was aimed at students from Year 9 through to Year 12 studying at schools in Catalonia. Each student participated with a poem or short story inspired by light, optics and photonics. We accepted submissions written in Catalan, Spanish or English, with a maximum length of 1000 words. Each school sent a maximum of two compositions per class. The panel of judges chose the four best compositions by students in Year 9 and Year 10, and the five best compositions by students in Year 11 and Year 12. The winning submission served as the starting point for the composition of a song by a musical group. A total of ten groups participated. The groups could change the original words to better fit the music. The songs, along with the original winning texts, were presented in the form of a CD-book. Prizewinners, musicians, judges, participating schools and collaborators involved in the project were given a copy of the CD-book. All songs were played at a final concert at La Pedrera de Barcelona, thanks to the collaboration of Fundació Catalunya-La Pedrera ${ }^{11}$. The musicians have the right to make use of the songs as and when they please, given that the authors will own the copyright on the lyrics.

\subsection{The prize}

Arguably, the best prize an author can wish for is having readers. There is something even better, and that is to have the ability to inspire others. The prize of the contest aimed exactly at this: to assure the young writers with the confidence of inspiring other artists, namely the musicians.
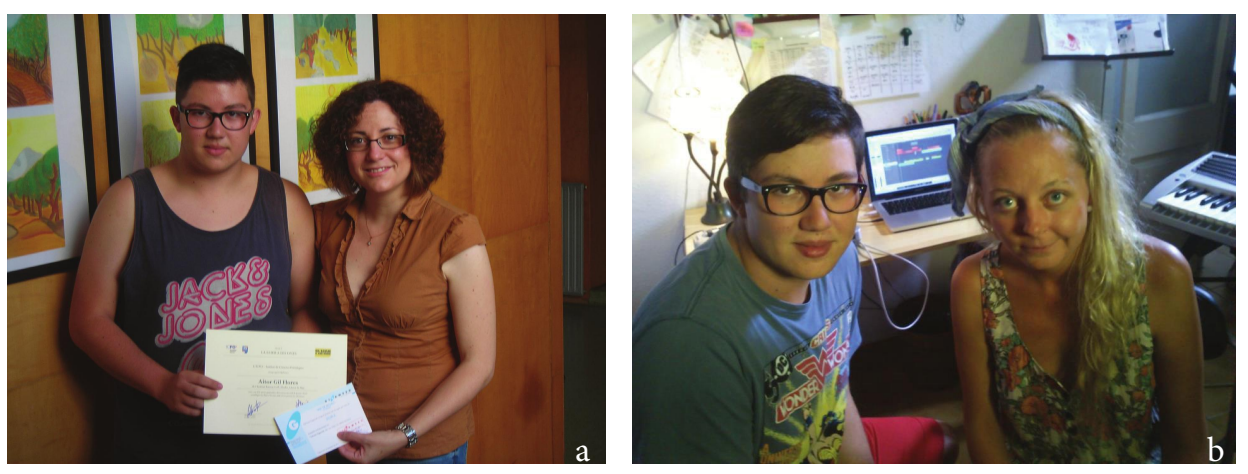

Fig 2. The process of the contest. (a) Aitor Gil and his music teacher, Alícia Fernández, holding the diploma. (b) Aitor and Miss Q during the composition of the song. (c) Miss Q at the Light on the Waves Concert singing Aitor's Lyrics. (d) Aitor, Miss Q and Daniel Setti (drums) at the end of the concert. (c) (d) CPepe
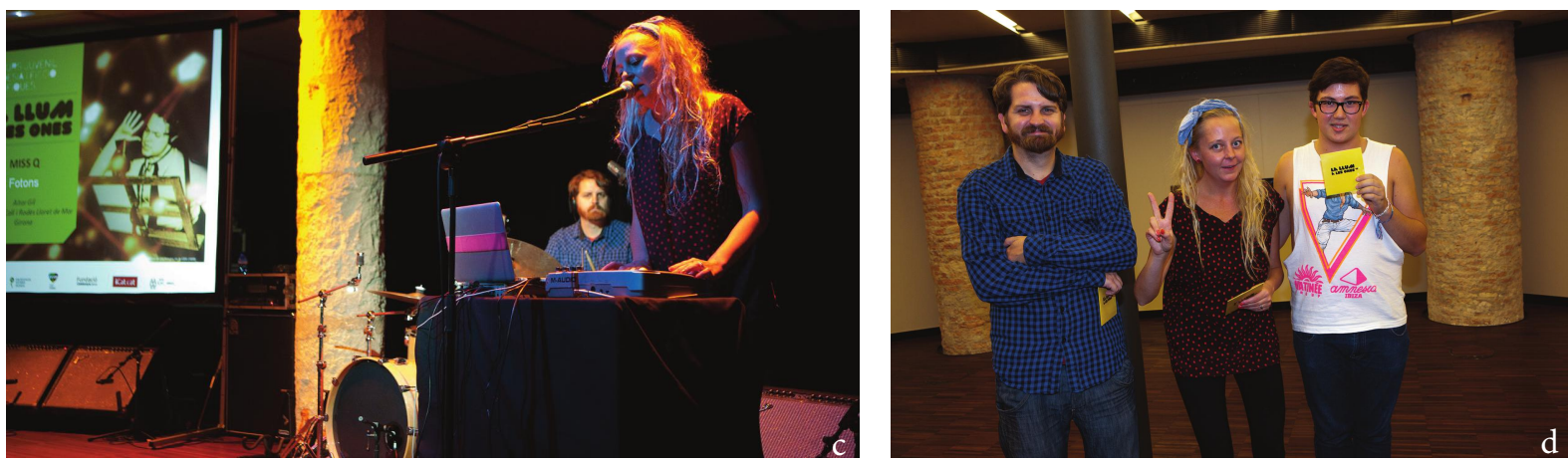

The musicians were involved in the project through an informative campaign described in section 3.2. Once they received the lyrics, which were distributed among them according to their preferences, the composition period started. The author of the lyrics met the musicians soon after. During the interviews the musicians explained the students the creative process of composing a song, and both had the opportunity to talk about the text and share the experience of turning it into a song. All songs can be listened to in the web page of the project ${ }^{3}$. 
Fig 2. above illustrates the four steps of the process of the contest: Aitor Gil, from high school Ramon Coll i Rodes, de Lloret de Mar, Girona, is one of the winners of the 2012 edition. During the summer he met the composer and singer of electronic music Miss Q in her studio at Barcelona. The song was played at the concert and also recorded in a CD with the rest of compositions. It is worth mentioning that Miss Q included the track "Photons" in her new album Tirol".

The process initiated a collaboration that exploited musicians' and students' creativity around the topic of science and ended with strong link between them. The prize was completed by a set of books donated to each school by Gigamesh, a well known science-fiction bookstore in Barcelona ${ }^{5}$, including titles by Fredric Brown, Angelica Gorodischer, Tim Powers, Neal Stephenson, Arkady and Boris Strugaski, and others.

\subsection{Inspiration}

The inspiration of the whole project can be described using the verses of Spanish romantic author Gustavo Adolfo Bécquer "As long as one mystery remains for mankind / there will be poetry!" (Mientras haya un misterio para el hombre / ¡habrá poesía!) A mystery gives rise to poetry, but also to science and music, because these three disciplines have one thing in common: they can transport us where no one has been before. To reach a new world means in a certain sense to create it, and creativity is as essential for science as for any artistic process. As we say in the motivation for students $^{6}$, "to reach the places where no one has been before, one has to use a personal and unique door. We are curious about your door, and that's why we want to read your texts inspired by light."

Besides the ability of poetry to transmit ideas, we were also interested in stories. Stories have always been a powerful way of transmitting ideas and values. Scientific concepts are not an exception. People may or may not understand a scientific idea, or appreciate its beauty or its utility, but for sure they will follow with strong interest a good story built around it. Writing a story with characters and plots familiar to objects and processes of science is a wonderful way to get a student into reading about science. We added special references for the students to get inspiration ${ }^{7}$ : Micromegas, Voltaire (1752); Morel's invention, Adolfo Bioy Casares (1940); Red grass, Boris Vian (1950); Cronopios and Famas, Julio Cortázar (1962); Cat's cradle, Kurt Vonnegut (1963); Cosmicomics, Italo Calvino (1964); The Hitchhiker Guide to the Galaxy, Douglas Adams (1979) and others.

\subsection{Agenda}

The project started with the kicking off of the website and the sending to all centers around Catalonia of the announcement of the contest, at the beginning of February of 2012. The deadline for the handlings of the texts was April 24. The jury evaluated the texts until the first of June of 2012. The winners were then announced and the musicians chose their selections. During the months of June, July and August, most of the meetings between authors and musicians took place and the songs were composed. At the beginning of September, the songs were recorded. The 28 of September we celebrated the final concert in La Pedrera de Barcelona.

\section{PILLARS}

The organization of the project is based in three pillars: the teachers, the musicians and the jury.

\subsection{Teachers}

Teachers are fundamental in this project for several reasons. Their knowledge and continuous feedback was critical to shape the program from the very beginning, and to keep improving it in the different editions. Also their involvement is crucial to get the students into writing and their constant motivation helps them throughout all the process. We presented the project at schools as a multidisciplinary project involving teachers of physics, literature, history, philosophy, art, music, etc. The teachers were responsible for creatively implementing the program at their respective centers. In most 
cases, the organizer was the Physics teacher, although in a considerable number of centers the leaders of the project were teachers from Literature, Art or Music, who searched for punctual collaboration from the science seminar. Teachers also collect the information of the contests from ICFO and transmit it to the students. Teachers are also the bridge between the students and the musicians and the students and ICFO for all practical matters.

The teaching of optics at schools usually starts at Year 10, although some schools start at Year 9 with basic geometric optics. Common topics in Years 9 and 10 are refraction, reflection, diffraction and polarization, while in Years 11 and 12 we enter wave-particle duality, electromagnetism, relativity, and in a less extent lasers and advanced photonics. We identified three main types of teacher participation: (1) Physics teachers that use the contest to motivate the students to think about physics concepts studied at the classroom; (2) Literature or music teachers that ask students to create or collect a glossary with terms related to optics and photonics and to compose a text using the meanings evoked by the words in it; (3) Teachers that ask the students to write about a more general concept of light. As it will be discussed in Section 5., not all compositions were science or science fiction pieces. A big proportion of the participants used the inspiring power of terms related to light to

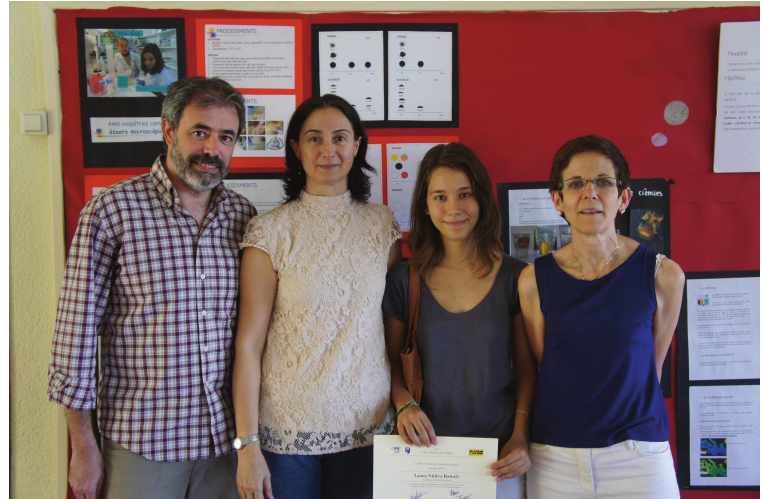

Figure 3. Laura Núñez (third from the left) from Virolai School, Barcelona, with his Physics teacher, her mentor, and the director of the center. compose stories or poems about their feelings or their lives.

When asked about their opinion about the program, teachers highlighted two main virtues: First, an innovative educational tool that motivates students and teachers. Second, an extremely useful means of spotting unknown skills of students. More interestingly, some teachers greatly appreciate how this kind of activities gets a usually shy or silent student to be more appreciated among their classmates.

\subsection{Musicians}

Musicians were our "allies on the streets". It was a gratifying surprise to discover their curiosity and their enthusiasm when we laid on them the idea of working on the subject of science and heads up with teenagers. They showed an overwhelming willingness to collaborate, to jump into the project.

We were searching for musicians that could perform as mentors of the kids as well as colleagues and amplifiers of their work. The musicians had to have the ability to understand the "new world" the author was creating when writing the

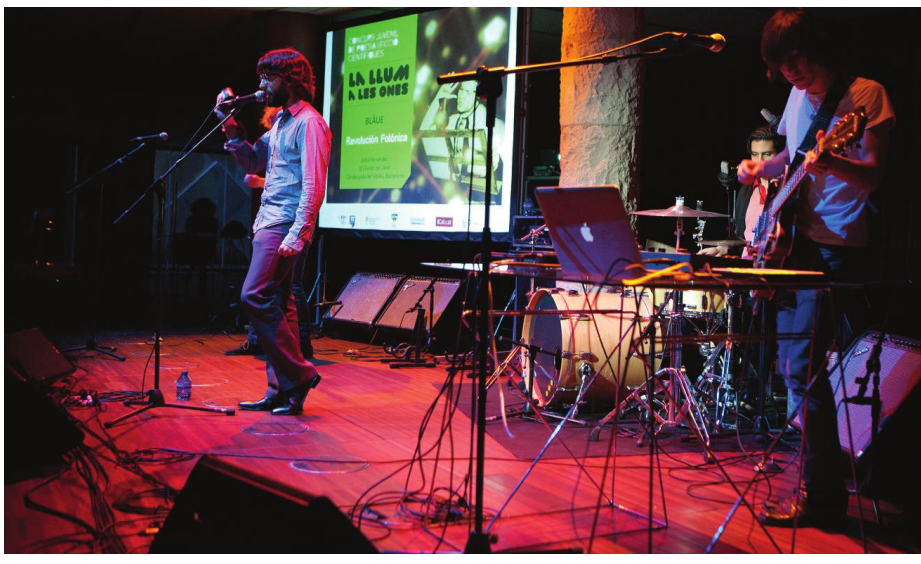

Figure 4. The band Bläue leaded by Adrià Casas, playing a song based on a story of Alba Hernandez about a revolution of photons. CPepe Molina text. They had to have the ability to furnish it, complement it, and then amplify it by composing a song that should transmit the same message. Working on somebody else's text could represent a restriction that would not benefit the original creation. Thus, getting a good match authormusician is crucial for the results of the whole project. We needed to find high quality musicians, sensible, curious and with an enormous creativity potential.

The process of searching musicians was not an easy task. Besides looking for high quality musicians with a willingness to participate in a process like this, the whole project demanded that they volunteer for the program. We contacted several record labels, mostly independent. They reacted astonishingly fast contacting the musicians they thought could be 
interested in participating. Soon we started meeting all the bands and talking about the project. The benefit for the bands, besides the experience of participating in an inspirational activity related to science, was also increased by the fact that with this activity they will gain visibility and potentially open their music to teenagers -and, not to be underestimated, their parents.

\subsection{The jury}

Scientists and writers formed the external jury with a renowned trajectory in their respective fields. They represented our commitment to science and literature. The jury included David Jou, Professor of condensed matter physics at the Autonomous University of Barcelona (UAB) and a referent in scientific poetry. He has published six books and two hundred research papers in physics, twenty books of poetry and eight books of essays; Joan Duran, poet and a PhD in biochemistry. He combines literary work, research and teaching at the University of Barcelona. He is the director of the Poetry Festival in Sitges. Dolors Udina, literary translator and professor of translation at the Faculty of Translation and Interpreting at UAB. She has translated more than one hundred novels by authors such as J. M. Coetzee, Toni Morrison, Raymond Carver, Nadine Gordimer, J. R. R. Tolkien and Jane Austen. In the second edition we also counted with Miquel Barceló, Professor at the Faculty of Computer Science of Barcelona, and a hey writer, editor, translator and specialist in science fiction, which he frequently uses as a tool for science teaching.

\section{RESULTS}

We received contributions ranging from short stories, to philosophical essays, to poems about the double-slit experiment. It is particularly interesting to highlight the wide range of styles in the contributions as well as the wide range of musical styles of the bands. As a nice anecdote, at the time of choosing the texts, each band chose as a first option a different text, so we got a optimally satisfying matching!

\begin{tabular}{|c|c|c|c|c|c|c|}
\hline Student & School & City & Band & Band Type & Text & Text type \\
\hline Jesús Badenes & Aula Escuela Europea & Barcelona & Joan Colomo & Folk music & Lux, Lucis & $\begin{array}{l}\text { Philosophical } \\
\text { essay about } \\
\text { the nature of } \\
\text { light vs. the } \\
\text { nature of man. }\end{array}$ \\
\hline Karen Cortés & Institut La Bisbal & La Bisbal & D-Fried & Electronic & $\begin{array}{l}\text { Llums, estrelles } \\
\text { i memòries } \\
\text { Lights, stars, } \\
\text { and memories }\end{array}$ & $\begin{array}{l}\text { Story about } \\
\text { heritage and } \\
\text { the value of } \\
\text { nature for } \\
\text { tradition } \\
\text { building. }\end{array}$ \\
\hline Aitor Gil & Ramon Coll i Rodés & Lloret de Mar & Miss Q & Electronic & $\begin{array}{l}\text { Sóc allà davant } \\
\text { There am I }\end{array}$ & Love poem. \\
\hline $\begin{array}{l}\text { Alba } \\
\text { Hernández } \\
\text { Fábrega }\end{array}$ & Forat del Vent & $\begin{array}{l}\text { Cerdanyola } \\
\text { del Vallès }\end{array}$ & Bläue & Rock & $\begin{array}{l}\text { Reunión fotónica } \\
\text { Photonic } \\
\text { gathering }\end{array}$ & $\begin{array}{l}\text { Story about a } \\
\text { bunch of } \\
\text { photons mad } \\
\text { at Earthlings } \\
\text { for inventing } \\
\text { the laser and } \\
\text { manipulating } \\
\text { photons. }\end{array}$ \\
\hline $\begin{array}{l}\text { Simon } \\
\text { Immerzeel }\end{array}$ & Aula Escuela Europea & Barcelona & Exxasens & $\begin{array}{l}\text { Progressive } \\
\text { rock }\end{array}$ & Light of the Day & $\begin{array}{l}\text { Poem about } \\
\text { selfperception. }\end{array}$ \\
\hline Eva Marin & Ramon Coll i Rodés & Lloret de Mar & Megaafonia. & Pop & $\begin{array}{l}\text { Tu ets la llum dels } \\
\text { meus somnis You } \\
\text { are the light of my } \\
\text { dreams }\end{array}$ & Love poem. \\
\hline
\end{tabular}


(table continues from page 5)

\begin{tabular}{|l|l|l|l|l|l|l|}
\hline Student & School & City & Band & Band Type & Text & Text type \\
\hline Laura Núñez & Virolai & Barcelona & Pulpopop & Catalan pop & $\begin{array}{l}\text { Resplendor } \\
\text { enganyosa }\end{array}$ & $\begin{array}{l}\text { Poem about } \\
\text { the power of } \\
\text { light }- \text { love. }\end{array}$ \\
\hline $\begin{array}{l}\text { Guillem } \\
\text { Ramírez }\end{array}$ & Josep Lluís Sert & Castelldefels & $\begin{array}{l}\text { Fernando } \\
\text { Lagreca }\end{array}$ & Electronic & $\begin{array}{l}\text { Dos amics } \\
\text { espacials }\end{array}$ & $\begin{array}{l}\text { Short story } \\
\text { about } \\
\text { friendship and } \\
\text { time-travel. }\end{array}$ \\
\hline $\begin{array}{l}\text { Maite } \\
\text { Gutiérrez }\end{array}$ & Baix Penedès & El Vendrell & $\begin{array}{l}\text { Lucy \& The } \\
\text { Bossons }\end{array}$ & Jazz & Noah y yo & $\begin{array}{l}\text { Short science } \\
\text { fiction } \\
\text { extraterrestrial } \\
\text { love story }\end{array}$ \\
\hline Nil Santané & Tossa de Mar & Tossa de Mar & Glissando & Pop & Thomas & $\begin{array}{l}\text { Poem about } \\
\text { light's wave } \\
\text { nature. }\end{array}$ \\
\hline
\end{tabular}

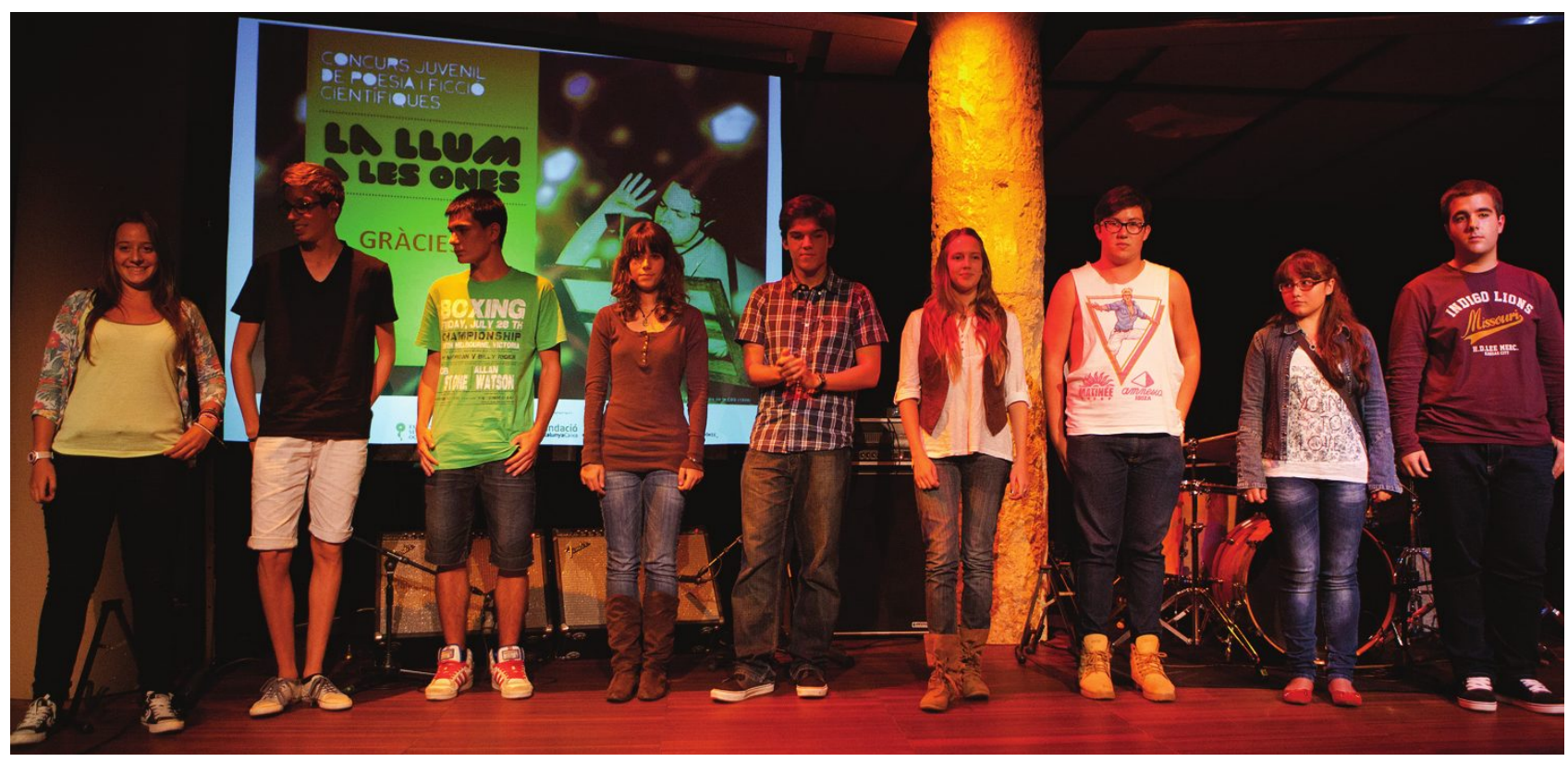

Figure 5. Winners of 2012 edition. From left to right: Eva Marin, Nil Santané, Guillem Ramírez, Laura Núñez, Simon Immerzeel, Maite Gutiérrez, Aitor Gil, Karen Cortés and Jesús Badenes. CPepe Molina

\section{CONTINUITY AND PRESENCE IN SOCIETY}

We believe an outreach activity could tremendously grow if it remains in the society once it is created, if it evolves into other formats, even after losing hold of their original creators. On March 15 and 162013 we presented a couple of events about our program at Kosmopolis ${ }^{8}$, a prestigious literary fest organized at Barcelona's cultural center $\mathrm{CCCB}^{12}$-this year devoted to science and literature. The events comprised a round table ${ }^{9}$ and a small concert ${ }^{10}$. At the round table, some of the participants in Light on the Waves, including musicians, students, teachers and members of the jury, explained the results of this collaboration. They talked during 90 minutes to expose their views on science as the subject artistic 
creation and on art and humanities as a tool for science education and outreach. At the mini-concert, we use some of the songs of Light on the Waves to explain the basic science of light to an audience of children and their parents. After the concert the audience were to create limericks inspired by light, which were put into music by the bands taking part in the concert. This activity gave rise to the project of composing a dictionary of photonics in limerick form ${ }^{14}$, following the example of OEDILF ${ }^{15}$, Omniscent English Dictionary in Limerick form.

We are also preparing a documentary about the process.

\section{ACKNOWLEDGEMENTS}

We would like to thank the crucial collaboration and implication of Fundació Catalunya-La Pedrera ${ }^{11}$, for supporting the project since the beginning, as well as for providing the wonderful venue La Pedrera. They help a lot in taking care of the organization of the concert. Special thanks to Salvador García Ruiz for believing in the project and Èlia Farrè and her team for all her help during the organization of the concert. We also are grateful to Centre de Cultura Comtemporànea de Barcelona $\mathrm{CCCB}^{12}$, for making possible the continuity of the project, hosting a number of events in the city related to the first edition of the project, and supporting the second edition, which will be celebrated at CCCB's premises. We also acknowledge Gigamesh Bookstore for donating the books for schools and the vouchers for students. Special thanks to Ramón Peña for welcoming all the winners at the bookstore and introduce them into new fascinating readings. Finally, we are really grateful to Montserrat Virgili from the radio station iCAT $^{13}$ for supporting and broadcasting the initiative. We warmly appreciate all support of the many ICFOnians that keep up the project at its many stages. Support by Fundació Cellex Barcelona and the Severo Ochoa Program is gratefully acknowledged.

\section{REFERENCES}

[1] http://obrasocial.lacaixa.es/laCaixaFoundation/home_en.html

[2] lallumalesones.icfo.es

[3] http://lallumalesones.icfo.es/2012/les-cancons/

[4] http://www.visitmissq.com/2013/04/tirol.html

[5] http://www.gigamesh.com/

[6] http://lallumalesones.icfo.es/2013/as-long-as-one-mystery-remains/

[7] http://lallumalesones.icfo.es/2013/para-los-autores/

[8] http://www.cccb.org/kosmopolis/en/edicio-k13-42017

[9] http://vimeo.com/channels/kosmopolis/65724493

[10] http://vimeo.com/channels/kosmopolis/65806495

[11] http://www.fundaciocatalunya-lapedrera.com/ca/home

[12] http://www.cccb.org/en/

[13] http://catradio.cat/icat

[14] http://lallumalesones.icfo.es/2013/limericks-2/

[15] http://www.oedilf.com/db/Lim.php 